\title{
Students' Mindset and Level of Anxiety for General Mathematics among Grade 11 Students: A Case of Jagobiao National High School, Philippines
}

\author{
Sheena Marie Y. Mabandos ${ }^{1 \#}$ \& Jerald C. Moneva ${ }^{2}$ \\ 1,2 Jagobiao National Highschool, Jagobiao, Mandaue City, Cebu, Philippines.
}

\#corresponding author

Type of Work: Peer-Reviewed

DOl: http://dx.doi.org/10.21013/jems.v16.n1.p6

How to cite this paper:

Mabandos, S.M.Y., Moneva, J.C. (2020). Students' Mindset and Level of Anxiety for General Mathematics among Grade 11 Students: A Case of Jagobiao National High School, Philippines. IRA International Journal of Education and Multidisciplinary Studies (ISSN 2455-2526), 16(1), 28-35. doi: http://dx.doi.org/10.21013/jems.v16.n1.p6

(C) Institute of Research Advances.

This work is licensed under a Creative Commons Attribution-Non Commercial 4.0 International License subject to a proper citation to the publication source of the work.

Disclaimer: The scholarly papers as reviewed and published by the Institute of Research Advances (IRA) are the views and opinions of their respective authors and are not the views or opinions of the IRA. The IRA disclaims of any harm or loss caused due to the published content to any party.

Institute of Research Advances is an institutional publisher member of Publishers International Linking Association Inc. (PILA-CrossRef), USA. The institute is an institutional signatory to the Budapest Open Access Initiative, Hungary advocating the open-access of scientific and scholarly knowledge. The Institute is a registered content provider under Open Access Initiative Protocol for Metadata Harvesting (OAl-PMH).

The journal is indexed \& included in WorldCat Discovery Service (USA), CrossRef Metadata Search (USA), WorldCat (USA), OCLC (USA), Open J-Gate (India), EZB (Germany) Scilit (Switzerland), Airiti (China), Bielefeld Academic Search Engine (BASE) of Bielefeld University, Germany, PKP Index of Simon Fraser University, Canada. 


\section{ABSTRACT}

In today's generation, mathematics will be very useful in our daily lives. Using mathematics is a tool when meeting life-related circumstances involving computation; hence mathematics is particularly important on a daily basis. This research study is entitled "Mindset and Level of Anxiety in General Mathematics among Grade 11 students". The study focused on the association between the mindset of the students if it is fixed or growth and their anxiety levels in General Mathematics. This research study is quantitative research; it is using a descriptive-correlation design. This study was answered by all Grade 11 students who are taking General Mathematics in the first semester in Jagobiao National High School. In gathering the data, the checklist survey questionnaire was being used. The result found out that students of Jagobiao National High School are more on growth mindset. Students with a growth mindset lead to a moderate level of anxiety in General Mathematics. By using the chi-square, it tells that mindset and level of anxiety has a significant difference. School heads, faculties, and staff can also have monthly activities to diminish the anxiety level of the students. They could also motivate or cheer up students to become growth-minded.

Keywords: Fixed Mindset, Growth Mindset, Math Anxiety

\section{Introduction}

General Mathematics is one of the core subjects of Grade 11 students. It has been taken by all Grade 11 students throughout the entire semester. General Mathematics also explores the various branches of Mathematics and their application in the real world (Department of Mathematics and Statistics). Mathematics anxiety is a psychology of personality that usually occurs in situations of teaching and learning in mathematical problem solving and evaluation [1]. The mindset has something to do with the student's level of anxiety. It can determine students' levels of anxiety by knowing the student's mindset. Mindset is a broad mechanism of psychology that reflects our esteemed behaviors, beliefs, and values [2]. There are two types of mindset: Fixed and Growth Mindset. A fixed mentality leads to less ability to learn, while growth provides a way to grow the creative potential [3].

Students have different social, emotional and scientific factors that can all be linked to different levels of mathematical fear [4]. There is a genuine fear of math among many students. During simple mathematical work, they are not only nervous and anxious, but they also avoid mathematics and mathrelated tasks [5]. Furthermore, students affect their motivation, learning and learning performance thoroughly whether they see their intellectuals as something set or something that changes and develops [6]. The attitude of the student thus has an influence on the anxiety of the student.

It has been observed that in Jagobiao National High School, the students have the characteristics of being fixed minded and growth-minded. Based on observations, students who have a fixed mindset have a higher level of anxiety whereas students who have a growth mindset have a lower level of anxiety. Fixed minded students are the students who limit themselves into one thinking and it will go to the negativity that will lead to a higher level of anxiety. Unlike growth-minded students, they can get a lower level because they widened their way of thinking to come up with new lessons and they think+ positively that they can do things.

Generally, this study aims to determine the effect of the student's mindset towards their level of anxiety in General Mathematics.

\section{Statement of Purpose}

This study intends to assess the level of anxiety in General Mathematics among Grade 11 students based on a fixed mindset and growth mindset.

Specifically, the study seeks to answer the following problems:

1 . What are the mindsets of students?

2. What is the level of anxiety of Grade 11 students in General Mathematics? 
3. Is there a difference between the mindset and level of anxiety in General Mathematics among Grade 11 students?

\section{Hypothesis}

$\mathrm{H}_{0}$ : There is no significant difference between the fixed and growth mindset and level of anxiety in General Mathematics among Grade 11 students.

$\mathrm{H}_{1}$ : There is a difference between the level of anxiety in a fixed and growth mindset in General Mathematics among Grade 11 students.

\section{Review of related literature}

In 2006, Carol S. Dweck formally introduced the word "mindset" in [7]. There are two types of mindset; fixed and growth mindset. Mindsets are a choice. A fixed mindset means an individual believes that skills and intelligence are unchanging, whereas a growth mindset means an individual believes that ability and intelligence are malleable attributes and can be enhanced and strengthened [8]. According to this concept of Fixed and Growth Mindset (FGM), a Fixed Mindset leads to a diminished cognitive ability, whereas a Growth Mindset offers a path to higher human potential levels [3]. People with a fixed mindset seem to believe that their values are set characteristics and cannot therefore alter. Instead of trying to develop and improve them, these individuals record their abilities and talents. Individuals that are having a fixed mindset often result to lower achievement in their studies. Typically, students with a fixed mindset saw their failures as a sign of their intellect, whether academic or not [9]. Whereas people with a growth mindset usually lead to higher achievement when it comes to education because they always think positively that they can improve their work with effort and perseverance. Students assumed that knowledge was malleable and could improve and they learned and evolved from their failures [9].

Mindsets are relatively stable, but through academic approaches, they can also be changed [10]. People can choose what mindset to use. Some study shows that people are fixed minded because of the approaches of the other people, they have been judged when they make mistakes. On the other hand, people that are growth-minded usually receive praise from others, also, they don't limit their knowledge even if they know that they can't do that. Mindset refers to the assumptions of an individual about the essence of their abilities-whether they feel that their ability is malleable or fixed in each domain [11].

Math is an important topic in education and career preparation; math skills are often a filter in career paths [12]. Mathematics devices have become part of one's daily lives from home to the workplace [13]. Mathematics is important in daily living, as it can be useful in every decision-making. Mathematics is one of the topics that has put great importance in the Philippines' education system [14]. Some students find Mathematics difficult to learn [15]. Most people have a real fear of math and panic feelings are common [5].

The fear of math is called math anxiety. Anxiety about mathematics tends to significantly affect performance in mathematics [4]. Math anxiety is a sensation of stress and anxiety that interferes with mathematical manipulation and math problem-solving in a wide range of ordinary life and educational circumstances [16]. Anxiety in mathematics refers to such negative mood responses that arise when some students experience problems in mathematics [17]. Psychologically, math anxiety suggests a negative attitude towards solving mathematical problems that affect the learning habits and results of students [13]. This shows that negative math emotions, including an unwillingness to engage in the assignments in this class, are feeling ill and tired of mathematical tasks and related courses [18].

Millions of students in math classes wonder why they must study numbers and equations, but they are not doing well in mathematics. They can't even multiply or divide; perhaps they can see any connection between mathematics and their own lives [19]. When coping with any math-related situation, math anxiety is generally known as feelings of fear, avoidance, and dread [20]. Mathematics anxiety can be found in all ages, from pre-school to graduate students and beyond [19]. One of the reasons why students have anxiety it is because of their mindset. Students with high anxiety in mathematics tended to score low in their attitudes towards mathematics. However, those with low anxiety in mathematics tended to have a high score in mathematical thinking and attitudes in mathematics [21]. Students experience a sense of self-threat in studying mathematics, leading to a loss of interest in mathematics and a loss of confidence in learning mathematics [17]. Increases in math anxiety decrease in math success [12]. Today, society's demands need 
more mathematics and to reduce math anxiety, math must be looked at in a positive [22]. Mathematics does not need to be stressed, although this may still be appreciated even if it is not simple as interpreted by the majority. The subject's enjoyment is focused on the meaningfulness and complexities of the demonstrated definition [14].

As stated before, mindsets are a choice. People can be fixed minded or growth-minded and that would lead to anxiety when talking about mathematics. High-level students have lower levels of anxiety, while low-level mathematics students have high levels of anxiety [20]. Studies have shown that errors are valuable learning and development opportunities, but students often perceive errors as measures of their low capacity [23]. Promoting a culture of growth mindset would require schools to shift towards grouping activities that do not mark or send negative messages to students and teaching strategies that respect all students ' thoughts, challenges, and diverse learning paths [23]. By concentrating on a growth mindset of progress, students will embrace the positive inclusion of failure in the wider learning picture, rather than the urgent need for instant academic success [24].

Academic variables such as the use of traditional teaching styles as well as teachers who have associated anxieties with teaching and/or the associated presentation of mathematics material may also theoretically affect the anxieties of students concerning learning mathematics concepts [4].

As a result, the anxiety level of the students will depend on their mindset. If they are fixed minded then they could have a higher level of anxiety, while if they are growth-minded, then they will have at least a lower level of anxiety.

\section{Methodology}

This section contains the research design used by the researcher, the research environment, the respondents of the study, the instruments used, and the data gathering procedure of this research study.

\section{Design}

This research study is using a descriptive-correlation design. It assesses the difference between the mindset and level of anxiety in General Mathematics among grade 11 students in Jagobiao National High School.

\section{Locale}

The study is conducted in Jagobiao National High School of Jagobiao Mandaue City. By 2015, this school has been part of the K to 12 curriculum program. The Senior High School offers TechnicalVocational and Livelihood (TVL)- Drafting and Academic Tracks such as Accountancy, Business and Management (ABM), General Academic Strand (GAS), Humanities and Social Sciences (HUMSS), and Science, Technology, Engineering and Mathematics (STEM).

\section{Respondents}

The respondents of this study are the Grade 11 Senior High School students in each strand (ABM, GAS, HUMSS, TVL, and STEM) in Jagobiao National High School. This research study has an overall number of 158 respondents. These students were chosen because they were qualified to answer the following questions about the mindset and level of anxiety in General Mathematics.

\section{Instrument}

In this study the researcher intends to use the checklist survey questionnaire as a research tool instrument which adapted from the study of Nist and Diehl (1990) in gathering the data for the level of anxiety which has the scaling rate of (1) for negligible, (2) for low, (3) for moderate, (4) for high, and (5) for at risk. For the mindset, we have the study of P'Pool (2012) which also a separate rating scale of (1) for never, (2) for seldom, (3) for neutral, (4) for often, and (5) for always as this is the appropriate tools for gathering data and information in a quantitative research. 


\section{Data Gathering Procedure}

The researcher will ask permission from the students to be the respondents of this research study with the help of the letter of consent signed by the teachers and principal.

The respondents will be given questionnaires and they will check their answers on the questionnaires themselves. After distributing the questionnaires to the respondents, the researcher will give enough time to the respondents to answer the questions given. If the respondents are done answering the questions, their papers will be collected and the researcher will give their appreciation to the respondents for cooperating. The result of the collected papers will be the researcher's basis for the analysis, interpretation, findings, conclusion, and recommendation of the study.

\section{Statistical Treatment}

To interpret the data effectively, the researcher will employ the following statistical treatment. Chi-square is used to treat the data that are gathered while Weighted Mean is used for assessing the Level of Anxiety in General Mathematics among Grade 11 students based on their Mindset.

\section{PRESENTATION, ANALYSIS, AND INTERPRETATION OF DATA}

This chapter represents the findings, analysis, discussion and interpretation of data gathered from the Senior High School students of Jagobiao National High School.

Table 1. MINDSET

\begin{tabular}{llc}
\hline Indicators & WM & Interpretation \\
\hline 1. To be honest, I can't really change how intelligent I am. & 2.77 & Neutral \\
2. I have a certain amount of intelligence, and I really can do much to change it. & 3.17 & Neutral \\
3. No matter what I do, I can significantly change my intelligence level. & 3.13 & Neutral \\
4. I can't always substantially change how intelligent I am. & 2.89 & Neutral \\
5. I can learn new things, but I can't really change my basic intelligence. & 3.13 & Neutral \\
6. No matter how much intelligence I have, I can always change it quite a bit. & 3.26 & Neutral \\
7. I can't change even my basic intelligence level considerably. & 3.06 & Neutral \\
8. No matter what I do, I can always learn. & 3.55 & Often \\
9. No matter how much I study hard or not; I can always change my level of & 3.35 & Neutral \\
intelligence. & & \\
10. No matter how much I study hard; I can always change my level of & 2.96 & Neutral \\
intelligence. & 3.13 & Neutral \\
\hline Overall weighted mean & &
\end{tabular}

$\mathrm{N}=158$ 1.00-1.80 Never 1.81-2.60 Seldom 2.61-3.40 Neutral 3.41-4.20 Often 4.21-5 Always

The table above shows the mindset of the students wherein statement 8 has the highest weighted mean of 3.55 with the interpretation of often, while statement 1 has the lowest weighted mean of 2.77 with the interpretation of neutral, while the rest has the range weighted mean of 2.89-3.35 with the interpretation of neutral. The researcher decided the scaling, as 1 is fixed while 5 as the growth. The overall weighted mean is 3.13 with an interpretation of neutral which means that most of the students are growth-minded. Research evidence suggests that one's mentality affects pattern recognition. With a fixed mindset, pattern recognition often tends to be difficult when learning a new ability [25].

Those who believe their ability to improve their domain through effort have a growth mentality while people who believe their domain is unchangeable have a great mentality, as was originally claimed by Dweck and colleagues [11]. Nevertheless, we can actively adjust our attitude with suitable skills and conditions[3]. 


\begin{tabular}{lcc}
\hline Indicators & Frequency & Percent \\
\hline Fixed Mindset & 0 & 0 \\
Becoming Fixed Mindset & 6 & 2.9 \\
Neutral & 72 & 34.3 \\
Becoming Growth Mindset & 70 & 33.3 \\
Growth Mindset & 10 & 4.8 \\
\hline Total $(\mathrm{N})$ & 158 & 75.2 \\
\hline
\end{tabular}

The table above shows the frequency and percentage of the students' mindset. As we can see, students in Jagobiao National High School are not fixed minded, but, out of 158 students, there are 6 students who are becoming fixed. The majority of the students are neutral which means they have a fixed mindset and growth mindset. In addition, 70 students are becoming growth and 10 out of 158 are really having a growth mindset.

Table 2. ANXIETY

\begin{tabular}{llc}
\hline Indicators & WM & Interpretation \\
\hline 1. I have visible signs of nervousness such as sweaty palms, shaky hands, & 3.09 & Moderate \\
and so on right before a test. & 2.51 & Low \\
2. I have "butterflies" in my stomach before a test. & 2.44 & Low \\
3. I feel nauseated before a test. & 2.85 & Moderate \\
4. I read through the test and feel that I do not know any of the answers. & 2.56 & Low \\
05. I panic before and during a test. & 2.59 & Low \\
6. My mind goes blank during a test. & 2.95 & Moderate \\
7. I remember the information that I blanked once I get out of the testing & 2.63 & Moderate \\
situation. & 2.88 & Moderate \\
8. I have trouble sleeping the night before a test. & 2.78 & Moderate \\
9. I make mistakes on easy questions or put answers in the wrong places. & 2.73 & Moderate \\
10. I have trouble choosing answers. &
\end{tabular}

$\mathrm{N}=158$ 1.00-1.80 Negligible 1.81-2.60 Low 2.61-3.40 Moderate 3.41-4.20 High 4.21-5 At Risk

The table above shows the anxiety level of the students wherein statement 1 has the highest weighted mean of 3.09 with the interpretation of moderate, while statement 3 has the lowest weighted mean of 2.44 with the interpretation of low, while the rest has the range weighted mean of 2.51-2.95 with the interpretation of low to moderate as well. The overall weighted mean is 2.73 with an interpretation of moderate which indicates that the students of Jagobiao National High School have moderate anxiety during tests. Mathematics anxiety can be found in all ages, from pre-school to graduate students and beyond [19]. Mathematics is one subject that under any situation, pervades life at any age. The importance, therefore, goes beyond the school classroom [15]. As mathematical people face math tasks, they often have concerns about bad mathematical results and these worries tie up valuable thinking and reasoning resources needed for the task at hand [5].

\begin{tabular}{lrr}
\hline Indicators & Frequency & Percentage \\
\hline Not at all & 0 & 0 \\
Slight Anxiety & 17 & 10.8 \\
Fair Anxiety & 101 & 63.9 \\
Moderate Anxiety & 37 & 23.4 \\
With Anxiety & 3 & 1.9 \\
\hline Total (N) & 158 & 100 \\
\hline
\end{tabular}


The table above shows the frequency and percentage of the students based on their anxiety level. Thus, the study has shown that anxiety truly exists on students and most students do have an average level of anxiety. Out of 158 there 17 students who have a slight anxiety level. 37 students have moderate anxiety, 3 have a with anxiety and the majority of the students have fair anxiety which consists of 101 students out of 158 .

Table 3. MINDSET AND LEVEL OF ANXIETY

\begin{tabular}{lccc}
\hline & Value & df & Asymp. Sig (2-sided) \\
\hline Pearson Chi-Square & 13.944 & 9 & .124 \\
Likelihood Ratio & 14.364 & 9 & .110 \\
Linear-by-Linear Association & .360 & 1 & .549 \\
\hline N of Valid Cases & 158 & & \\
\hline
\end{tabular}

a. 812 cells $(100.0 \%)$ have expected count less than 5 . The minimum expected count is .01 .

The table above shows that there is no significant difference between the fixed and growth mindset and level of anxiety in General Mathematics among Grade 11 students since the p-value (.000) is lesser than the alpha (@=05). This means that the mindset and the level of anxiety of the grade 11 students have no significant correlation. Promoting a culture of growth mindset would require schools to shift towards grouping activities that do not mark or send negative messages to students and teaching strategies that respect all students' thoughts, challenges, and diverse learning paths [23]. Math anxiety is deeply rooted and is often triggered by the first formal math encounter of a child [22]. The cognitive role of the learning implies that students ' thought allows in the educational context to affect academic achievement [7].

\section{FINDINGS}

This study is all about "Mindset and Level of Anxiety in General Mathematics among Grade 11 students", where the researcher conducted a survey that made use of the checklist survey questionnaire in knowing the mindset and their level of anxiety.

The data portrays that the mindset of the students is correlated with their anxiety level therefore, it is significant. It implies that having a fixed mindset can result in a high level of anxiety whereas having a growth mindset can result in a lower level of anxiety.

Using the chi-square, the researcher identified that there is a significant difference between the student's mindset and their level of anxiety in general mathematics. All in all, having a fixed or growth mindset does seem to affect the student's anxiety.

\section{CONCLUSION}

The result of the study shows that the mindset of the students, whether it is fixed or growth, will affect their level of anxiousness. It is significantly connected to what is being forecasted by the researcher. The mindset of the students can significantly change or affect the student's level of anxiety in general mathematics based on the result of the computed value of chi-square. Students can decide what mindset to use, either fixed or growth mindset to develop. Results show that students in Jagobiao National High School possess a growth mindset and have a moderate level of anxiety in General Mathematics. Overall, no matter what the student's mindset is, they will really have anxiety levels.

\section{References}

[1] Alam al-Hoda H, (2000). Mathematics anxiety. Journal of Psychology and Educational Sciences, 5(1).

[2] Schein, S. (2015). A new psychology for sustainability leadership: The hidden power of ecological worldviews. Sheffield, UK: Greenleaf.

[3] Buchanan, A., and Kern, M. L. (2017). The benefit mindset: The psychology of contribution and everyday leadership. International Journal of Wellbeing, 7(1), 1-11. doi:10.5502/ijw.v7i1.538 
[4] Alzahrani, A., and Stojanovski, E. (2017). Assessment of anxiety on mathematics for students in a secondary school in Qatar. International Congress on Modeling and Simulation, 1517-1522. Mssanz.org.au/modsim2017

[5] Beilock, S., and Maloney, E. (2015). Math Anxiety: A factor in math achievement not to be ignored. Policy Insights from the Behavioral and Brain Sciences, 2(1), 4-12. doi: 10.117712372732215601438

[6] Dweck, C. S. (2006). Mindset: The new psychology of success. New York, NY: Random House.

[7] Zhang, J., Kuusito, E., and Tirri, K. (2017). How teachers' and students' mindset in learning have been studied: Research findings on mindset and academic achievement. Scientific Research Publishing, 8, 13631377. doi:10.4236/psych.2017.89089

[8] Bazelais, P., Lemay, D. J., Doleck, T., Hu, X. S., Vu, A., and Yao, J. (2018). Grit, mindset, and academic performance: A study of pre-university science students. EURASIA Journal of Mathematics, Science and Technology Education, 14(12), 1-10. https://doi.org/10.29333/ejmste/94570)

[9] Rhew, E., Piro, J. S., Goolkasian, P., and Cosentino, P. (2018). The effects of a growth mindset on selfefficacy and motivation. Cogent Education, 5, 1-16. https://doi.org/10.1080/2331186X.2018.1492337

[10] Rissanen, I., Kuusisto, E., Tuominen, M., and Tirri, K. (2019). In search of a growth mindset pedagogy: A case study of one teacher's classroom practices in a Finnish elementary school. Elsevier Ltd, 77, 204-213. https://doi.org/10.1016/j.tate.2018.10.002

[11] Burgoyne, A. P., Hambrick, D. Z., Moser, J. S., and Burt, S. A. (2018). Analysis of mindset intervention. Journal of Research in Personality, 77, 21-30. https://doi.org/10.1016/j.jrp.2018.09.004

[12] Ashcraft, M., and Krause, J. (2007). Working memory, math performance, and math anxiety. Psychonomic Bulletin \& Review, 14(2), 243-248. https://link.springer.com/article/10.3758/BF03194059

[13] Das, R., and Das, G. C. (2013). Math anxiety: The poor problem solving factor in school mathematics. International Journal of Scientific and Research Publications, 3(4), 1-5. http://www.ijsrp.org/research-paper0413/ijsrp-p16134.pdf

[14] Guita, G. B., and Tan, D. A. (2018). Mathematics anxiety and students' academic achievement in a reciprocal learning environment. International Journal of English and Education, 7(3), 112-124. file:///E:/Journal\%2012\%20of\%20Anxiety.pdf

[15] Salinas, K. J., Tolibao, J., and Moneva, J. (2019). Student's anxiety in mathematics. International Journal of Novel Research in Education and Learning, 6(1), 46-55. www.noveltyjournals.com

[16] Eden, C., Heine, A., and Jacobs, A. (2013). Mathematics anxiety and its development in the course of formal schooling-a review. Scientific Research, 4, 27-35. http://dx.doi.org/10.4236/psych.2013.46A2005

[17] Luo, X., Wang, F., and Luo, Z. (2009). Investigation and analysis of mathematics anxiety in middle school $\begin{array}{lllll}\text { students. } & \text { Journal }\end{array}$ http://educationforatoz.net/images/_9734_2_Xinbin_Lou.pdf

[18] Abbasi, M., Samadzadeh, M., and Shahbazzadegan, B. (2013). Study of mathematics anxiety in high school students and its relationship with self-esteem and teachers' personality characteristics. Procedia Social and Behavioral Sciences, 83, 672-677. doi: 10.1016/j.sbspro.2013.06.127

[19] Yamani, M., Almala, A., Elbedour, S., Woodson, K., and Reed, G. (2018). Math anxiety: Trends, issues, and challenges. PsycholClin Psychiatry, 9(1), 64-73. doi:10.15406/jpcpy.2018.09.00503

[20] Zakaria, E., Zain, N. M., Ahmad, N. A., and Erlina, A. (2012). Mathematics anxiety and achievement among secondary school students. American Journal of Applied Sciences, 9(11), 1828-1832. doi:10.3844/ajassp.2012.1828.18329

[21] Kargar, M., Bayat, S., and Tarmizi, R. A. (2010). Relationship between mathematical thinking, mathematics anxiety and mathematics attitudes among university students. Procedia Social and Behavioural Sciences, 8, 537-542. doi: 10.1016/j.sbspro.2010.12.074

[22] Rossnan, S. (2006). Overcoming math anxiety. Mathitudes, 1(1), 1-14.

[23] Boaler, J. (2013). Ability and Mathematics: the mindset revolution that is reshaping education. Forum, 55, 143-152. https://www.youcubed.org/wp-content/uploads/14_Boaler_FORUM_55_1_web.pdf

[24] Pueschel, A., and Tucker, M. L. (n.d.). Achieving grit through the growth mindset. Journal of Instructional Pedagogies, 20, 1-10. https://files.eric.ed.gov/fulltext/EJ1178729.pdf

[25] Vandewalle, D. (2012). A growth and fixed mindset exposition of the value of conceptual clarity. Industrial and Organization Psychology, 301-305. doi:10.1111/j.1754.9434.2012.01450.x

[26] Mutawah, M. A. A. (2015). The influence of mathematics anxiety in middle and high school students math achievement. International Education Studies, 8(11), 239-252. doi:10.5539/ies.v8n11p239 